\title{
Halal Holidays: Exploring expectations of Muslim-friendly holidays
}

\section{Fiona Wingett and Sarah Turnbull}

\begin{abstract}
:
Purpose: The purpose of this study is to explore the expectations of Muslim tourists when taking a halal holiday. Understanding consumer expectations is an important factor in any service context since expectations determine whether the consumer is satisfied or dissatisfied with the service outcome.
\end{abstract}

Design/methodology/approach: An exploratory approach was adopted and in-depth interviews with Muslim tourists and halal holiday providers were undertaken.

Findings: The findings identified services and facilities Muslim consumers expect from a halal holiday and those they did not expect to see. Factors such as halal food, women-only facilities and dress codes were identified as services and facilities that are expected, whereas no alcohol was seen to be an important factor for Muslim tourists.

Research limitations/implications: This exploratory study used a small sample and hence the findings should not be seen to be generalisable. However, the study provides a number of valuable insights into the expectations of Muslim leisure tourists. Halal travel organisations and tourism boards will benefit from a better understanding of factors that influence the satisfaction/dissatisfaction of Muslim tourists.

Originality/value: The study makes three main contributions to our understanding of halal holidays. First, the study identifies expectations that are likely to influence satisfaction, such as halal food and women-only facilities. Second, the study highlights those expectations which are likely to cause dissatisfaction for halal holidaymakers, such as alcohol and dress codes. Third, the study highlights the difference in expectations which exist between halal holidaymakers and how the interpretation and practice of Islam is highly varied. 


\section{Introduction}

Although halal tourism is a relatively recent phenomenon, halal holidays for leisure purposes are estimated to be one of the fastest growth sectors in the industry. Already worth over $\$ 126$ billion, the halal holiday sector (not including Hajj or Umrah travel) is predicted to grow to $\$ 192$ bn by 2020 (Dinar Standard, 2012). This booming tourism sector has attracted considerable attention from both industry and the media (Reeve, 2012; Suleaman, 2010).

While the motivations of travel undertaken by Muslims for spiritual purposes, such as pilgrimages like Hajj or Umrah is clear, we have less understanding regarding the expectations of Muslim tourists seeking leisure holidays. In particular, we have limited knowledge regarding the facilities and services Muslim tourists expect when taking a halal holiday for leisure purposes.

Understanding the nature of customer expectations is important as they act as a benchmark to confirm or disconfirm whether desired levels of service have been reached. In the service marketing literature expectations are seen to be a central measure in determining customer satisfaction and service quality (Parasuraman, Berry, and Zeithaml, 1991; Zeithaml, Berry, and Parasuraman, 1993; Ojasalo, 2001). Hence a better understanding of halal tourists' expectations would be valuable.

Customer expectations are influenced by culture and values and hence it is important to consider the differences which exist between Muslim consumers. The diversity of the Muslim community (ummah) and differences in adherence to the tenets of Islam between communities both within and between different countries, within socioeconomic groups and varying cultures is significant because of the different approach, attitude and interpretation 
towards, and of, the religious tenets (Sandikci, 2011). Furthermore, interpretation of the term halal is seen to vary (Wilson and Liu, 2010). For this reason, it is important to explore the differences which may exist between Muslim tourists and gain a better understanding of what expectations consumers have regarding a halal holiday.

\section{Literature review}

The nature of service expectations

Customer expectations are seen to be the 'wishes' that a customer has about future service delivery (Coye, 2004). Understanding expectations is seen to be central to customer satisfaction since expectations provide a benchmark to confirm or disconfirm if levels of service have been met (Parasuraman, Berry and Zeithaml, 1991; Zeithaml, Berry, and Parasuraman, 1993). When a customer's expectation is met, that expectation is confirmed. However, if it is not, this results in disconfirmation, which can produce either positive (in that expectation was exceeded) or negative disconfirmation (expectations were not met) (Oliver, 1977; Yuksel \& Yuksel, 2001). Understanding expectations is therefore an important factor for service providers.

Grönroos (2007) sets out expectations within three key areas. First, Fuzzy expectations. These are expectations which customers feel should be met without being able to quantify exactly what they are and yet, without the service provider being able to meet them, the customer feels dissatisfaction. The service provider needs to make them explicit, or focus them, to be able to satisfy them (Ojasolo, 2001). Second, Explicit expectations are those which "consumers actively and consciously assume" will be met (Grönroos, 2007, p.100) and he warns against providing unclear sales messages which might mislead customers into assuming services they will not receive. Third, Implicit expectations are those which are "so 
obvious that they are never clearly expressed" (Gronroos, 2007, p.101) but which become an issue when they are absent.

Hence consumer expectations are an important factor for service brands to consider. A better understanding of consumers' expectations can help brands manage the service experience. To date there has been little consideration of expectations within the context of halal holidays and this study aims to redress this gap.

\section{Expectations of halal}

The term halal is associated with the Islamic faith and is an Arabic word meaning permissible (Wilson and Liu, 2010; Wilson 2014). As Wilson and Liu (2010, p.107) explain, "Halal, is central to every Muslim's belief - falling under the umbrella of what is considered to be information that is known by necessity". Halal is seen to reach beyond 'meat and money' (Wilson, 2014) and governs every aspect of a Muslim's life including; behaviour, speech, relationships and hospitality (Salleh, Hamid, Hashim and Omain, 2014; Rehman, Shabbir and Gill, 2010; Talib, Hamid, Zulfakar and Jeeva, 2014; Stephenson, 2013; Ali, Johari and Alias, 2014).". As Wilson and Lui (2010, p. 108) argue, "(halal) is part of a belief system and moral code of conduct, integral in daily living".

Rehman et al (2010, p.64) describe Islam as "an Arabic word which means absolute surrender to Allah (God). In Islam the source of power is Allah and all the creation (matter, energy, and life) obeys his laws. The Islamic system of life is called Shari'ah". He argues, "Violating Islamic values is named a crime while earning through halal (Shariahcompliant) is considered an act of worship... halal products are those that are Shariah compliant, i.e. do not 
involve: the use of haram (prohibited) ingredients, exploitation of labor or environment, and are not harmful or intended for harmful use. Muslims are obliged by religion to clearly scrutinize products to make sure they are halal. And, they are strongly encouraged by the Islamic teachings to shy away from consumables that are doubted." (Rehman, et al, 2010, p.64).

Hence there is widespread agreement in the literature that halal impacts and guides every aspect of a Muslim's life. However, it is apparent that differences in interpretation and practice of Islam vary greatly, not only between countries, but within and between cultures, age groups and other socio-economic demographics. Hence, Wilson and Liu (2010) warn against seeing Muslims as a homogenous group and identify the segmentation challenges which exist when developing halal brands. Additionally, they call for research to gain a better understanding of Muslim consumers.

Furthermore, there has been considerable debate in the literature around what constitutes a halal brand (Wilson and Liu, 2011, 2010; Wilson, 2014). Since the term halal is seen to have differing interpretations and as Wilson and Liu (2010p. 108) argue, "What is deemed Halal is ultimately governed by the heavens", agreeing on what makes a brand halal is challenging.

The literature calls for a better understanding of the halal phenomenon (Wilson and Liu, 2011).

\section{Defining a halal holiday}

Halal holidays are recognised in the literature as being one of a growing number of recent phenomena within 'crescent marketing' (Wilson et al, 2013). Reflecting the increasing 
attention given to the halal living sector, halal holidays include halal certified hotels and holiday packages (Wilson et al, 2013).

Although Muslims have long sought holidays which would not compromise their faith, according to Din (1989) it was Malaysia that first identified Muslim-friendly holidays as a distinct holiday market sector. Din argues that the Malaysian government's early identification of the niche market opportunity and its deliberate promotion of Malaysia in the Middle East as a "religiously 'clean destination' aimed at the Muslim segment of the market" was the beginning of the halal holiday market (1989, p.549).

In the literature, the term tends to be used to refer to leisure holidays designed with the needs of Muslims as its touchstone, but it does not generally encompass pilgrimages, like Hajj or Umrah. Nursanty (2013, p.2.) explains halal "tourism [as] a subcategory of religious tourism which is geared towards Muslim families who abide by Sharia rules".

Similarly, Hamza, Chohoud and Tantawi (2012, p. 86) describe Islamic tourism as being "about satisfying tourists looking for a destination that can fulfil their needs without being offensive in any way. At destinations where Islamic tourism is applied, tourists can count on feeling safe and secure knowing that only family-centred activities can be accessed. For Muslims, they can rely on having a completely halal good time without having to worry."

Referred to variously as 'halal holidays' (Nursanty, 2013), 'halal tourism' and 'Islamic tourism' (Battour, Ismail and Battor 2010; Zamani-Farahani and Henderson, 2010), there is variance in the name of the sector. In some cases halal holidays are described as Shariah- compliant by Salleh et al (2014). Hence the terminology used in the literature differs between scholars. 
The extant literature appears to focus on aspects of Islamic tourism which are important to travellers including, but not limited to, food, price, a Muslim-friendly atmosphere, segregated facilities, the provision of prayer rooms (Kärkkäinen, 2013), and special services during and the day light fasting month of Ramadan and the holy festivals of Eid-al-Fitr, Eid-al-Adha ("Halal foods most important", 2013), directional arrows in the accommodation (pointing towards the Islamic holy city of Mecca), conservative television channels free of adult content, toilets which do not face Mecca and hotels being alcohol-free (Alserhan, 2011).

The literature argues that Islam encourages travel (Timothy and Iverson, 2006; Hamza, Chouhoud and Tantawi, 2012). However travel should be undertaken for spiritual, social, health and physical benefits (Shakona et al, 2015). Din (1989, p.559) asserts it is meant to "be spiritually purposeful to make Muslims aware of the greatness of God, through observing the signs of history and natural and manmade wonders, all of which are gifts of God”. Further, Din (1989, p.552) posits “...the spiritual goal is to reinforce one's submission to the ways of God, the social goal which follows is to encourage and strengthen the bond of sillaturrahim (Muslim fraternity) among the Ummah (Muslim community)" and Sanad, Kassem \& Scott (2010, p.22) take a similar view, writing: "Islam entitles the right to journey from one place to another, tourism has to be of some purpose. It is not encouraged to escape from one's duties or to get away from one's dayto-day responsibilities."

Wilson and Hollensen (2013) present a cultural paradigm of Islamic life which is apposite. Their framework of cultural hierarchy highlights Islamic drivers, implicit norms and values as well as explicit practices which lead to tacit outcomes. The identification of the need for Muslims to consider the Islamic drivers, namely, worship and daily practice if they are to receive physical and spiritual nourishment is important. The need to worship and practice is a distinct driver of Islamic observance, whether at home or on holiday. 
In addition to differences in definitions, there is little known about service expectations. There has been limited exploration of the facilities expected (Battour et al, 2011) or drivers of holiday choice among Muslim tourists (Prayag \& Hosany, 2014), hence a better understanding of what Muslim consumers 'wish' for when choosing a halal holiday would be valuable.

The halal tourist

Pearce (2005, p.2) points to the immense diversity among tourists and, citing Nash, (2001), warns of the "sin of homogenisation" for analysts of tourist behaviour. The same is true for those attempting to understand the halal tourism market: segmenting the market by the term Islamic is ill-informed and could be short-sighted (Suerdam, 2013) and, for marketers, dangerous (Sandikci, 2011).

Within this paradigm it must be recognised that religion is a multi-dimensional construct and Islam comprises a heterogeneous population in many countries whose interpretation of Islam varies widely (Stephenson, 2013; Scott and Jafari, 2014; Dudley, 2013; Temporal, 2011; Battour et al, 2011; Sandikci, 2011, Mukhtar and Butt, 2012).

There are differences and complexities in the interpretation, understanding and practice of the principles of Islam (Dudley, 2013; Temporal 2011; Sandikci, 2011). How that complexity is further exacerbated by the culture of the country (Battour et al, 2011) and how strongly individuals adhere to the principles of Islam also needs to be considered. Temporal (2011) cites Turkey and Iraq as being at different ends of the scale regarding "religious conformity".

Even within countries, age, class, wealth, social status, education and other cultural factors may impact on that interpretation, and this has implications for the marketing of halal 
holidays. Indeed, Venkatesh (1995) asserts that an 'ethnoconsumerism' approach is needed within marketing to truly understand the needs of consumers from different cultures.

Similarly, Eickelman (1982, cited by Sandikci, 2011, p.253) urges that understanding "Islam in local contexts" is essential while Sandikci (2011, p.253) warns against a "onesize-fits-all- Muslims [approach]” because “...how halal unfolds in particular markets and product categories is very complex and dynamic". Conversely, she also cautions about Muslim consumers being depicted "as inherently different from consumers in general" which sets them apart "as if they have no shared characteristics at all" (2011, p.252).

However, while many scholars have highlighted the need to be aware of the difference in Muslim populations, there has been little attention given to how expectations differ between Muslim tourists. Hence the research aims to address the following question, What are the expectations of Muslim tourists when taking a halal holiday?

\section{Methodology}

The study used an exploratory approach and qualitative techniques to elicit textured, nuanced and complex data which would not be explained by quantitative methods. This is particularly apposite in this paradigm as little research has been previously conducted into this area (Denscombe, 2010). Following a grounded theory methodology allowed for the gathering of intricate details about how Muslims 'live' holidays and allowed the researchers to explore the emotions and feelings associated with halal holidays (Strauss and Corbin, 1998). Such an approach also allowed for the inclusion of context and underlying issues and for the complexity of real life (Miles, Huberman and Saldana, 2014). This approach also mitigated 
the possibility of causing offence in that the researcher was able to employ questions that were cognisant of the sensitivities of Islam.

The data was collected through a series of in-depth semi-structured interviews, using a set of open-ended questions designed not to lead the interviewee but to allow them to describe their thoughts and feelings. The semi-structured interviews were utilized in order to elicit deep, rich data from interviewees about their expectations of halal holidays. Using semi-structured interviews allowed for this complicated phenomena to be explored while retaining contextual "texturing” (Galletta, 2012, p.1).

As the focus of the current study was Muslim tourists, a non-probabilistic, purposive sampling approach was employed (Oliver, 2006) to. In total twelve Muslims were interviewed. See Table 1. There were distinct groups within the sample: halal travel experts; those who had been on a halal holiday and those who had not, but desired to do so. This population proved relatively difficult to access for a number of reasons, one of which may be that the researcher is not Muslim and therefore stands without the Ummah (Muslim community). Interviewees were recruited using a snowball sampling technique, whereby interviewees were asked to recommend others to take part (Brewerton and Millward, 2001). This was chosen as this strategy is seen to be appropriate for populations that are difficult to access (Brewerton and Millward, 2001).

[Insert Table 1 about

here]

The data was analysed concurrently with the data collection to encourage new and better data as themes emerge and to inform and energize the process (Miles, Huberman and Saldana, 2014). As each interview took place, notes were taken by one of the researchers in tandem 
with recording it digitally. Immediately afterwards the researcher listed the main themes which had emerged and then transcribed the interviews. Transcribed interviews were sent to participants for checking and clarification to increase the internal validity (Newman and Benz, 1998). Following this, the main themes within the data were identified and listed.

Themes were considered both within the categories and across them.

Reflexivity was used throughout the process to enhance the quality of the study (Creswell, 2014). The themes were not coded for importance to the individual and neither were they set against their religiosity, as many found it impossible to describe how religious they were within Islam and found it impossible to separate some themes in terms of importance. The main themes that emerged from the data are discussed below.

\section{Findings}

Six main themes emerged from the data. These were the expectations interviewees had about halal holidays and were found to be: Not being exposed to haram; Muslimfriendly facilities and food; women-only facilities; dress codes; protecting children from alcohol and bad behaviour; and 'Living Islam'.

Not being exposed to haram

Most interviewees discussed the expectation that the resorts and hotels should be Muslim- friendly and they did not expect to be exposed to practices and products that would be haram. Expectations were that a halal holiday should allow them to go on a leisure holiday while 
remaining true to their religion and be free of the stress or guilt that other types of holiday may induce. A halal holiday was expected to provide a holiday that allowed them to observe their Faith and be in a 'safe' environment.

While there was an implicit expectation that there would be no alcohol served at the resort and halal food would be served, there was also the expectation that modest dress codes would be in place. There was some uncertainty that a halal holiday would be able to remove this risk. One interviewee described the discomfort he felt when he saw a Russian woman in a very revealing bikini walking on a 'family' beach. Another participant discussed the anxiety that seeing women exposed in swimming costumes on the beach would cause.

"If I ask my brother to come with me, or my husband, what concerns me is that in our religion when you see and keep looking [at women on a beach] then you will get some sin and if he gets sin it will be because of me and then I will be having sin as well." [PPH1]

For most, the expectation of a halal holiday was that they could enjoy a holiday without feeling guilty about exposing themselves or their family to anything haram. For those who had not experienced a halal holiday, the concept of taking a holiday and not feeling guilty about the experience was attractive.

"I am a practicing Muslim, a real devoted Muslim so ... when we travel, I do feel the inconvenience wherever we are and sometimes guilt. There are so many things Islam tells you not to do and when you travel you have to be exposed to ...things you don't want to be. Something like this there will be no guilt, plus convenience." [PPH3] 
Particularly for mothers of young children the expectation was that a halal holiday would reduce the risk associated with her children being exposed to haram practices. For one interviewee, protecting her children from haram behaviour was $a$ key consideration.

"I feel more comfortable...with what my kids are seeing...you can do your prayers together with people who are the same thinking and belief... and also as a mother you don't think about cooking or finding halal food." [HH2]

Other interviewees described how a halal holiday offered to provide them with "mental peace" [PHH5] as they did not have to ensure they were constantly worried about anything being haram.

"I am not going against Islam and I am maintaining my morals." [PHH5]

The difference in the interpretation and practice of Islam was highly apparent, even between two of the interviewees, For example, PHH3 would tolerate being on a cruise ship where alcohol is served, as long as it wasn't served at, or close to, her table, but her sister PHH1 would not consider even stepping on board.

Muslim-friendly facilities and food

Interviewees described the expectations they had regarding facilities and food on a halal holiday. Having halal food, an alcohol-free environment, separate male/female pools, beaches and gym and spa facilities, the presence of a prayer room or mosque was mentioned by most. 
"My second reason is a praying area, [having] convenient places to make your prayers. You have a separate mosque. For the men it is very important Friday prayers so you just show your whole brotherhood so you go to jum'a (Friday) prayers [HH2]

"A place where we can pray, that is important, and something to show us where the qibla [direction for praying] is" [PHH2].

As well as discussing what facilities and food they expected should be provided within a halal holiday, interviewees also discussed what they did not expect to encounter on a halal holiday. Alcohol was mentioned as one aspect of this and it was expected that a halal holiday resort would not serve alcohol. This related to expectations that Muslims had regarding not exposing themselves or their families to anything that was haram. The necessity for its absence was singled out by nine of the 12 participants as being important on a halal holiday, three interviewees specifically relating it to loutish and drunken behaviour from which they wished to protect their children.

Avoiding resorts that served alcohol and other tourists drinking alcohol seemed to be what attracted many to going on a halal holiday.

“My primary reason...wasn't because the hotel had a mosque...it wasn't because other Muslim families were there, if they had all been English and they hadn't been drinking and there weren't any bars, I probably would still have considered it. It wasn't religion [that made me go]."[HH3] 
The expectation was that a halal holiday should provide women-only facilities. Many women saw this as one of the main advantages of going on a halal holiday. Women discussed how having such facilities gave them the freedom to relax and enjoy their holiday. In particular separate swimming facilities, whether this was a women-only beach or swimming pool, was emphasised in their discussion.

"The main thing would have to be somewhere where there are facilities for women - where they could really let loose and enjoy themselves...Separate beach, spa facilities... and know that you can wear whatever you want.... Really it is about women being able to enjoy it in the same way a man does because...it is quite restrictive when you can't get into your swim gear." [PHH4]

"For me the halalness was to have a completely separate pool. I knew there would be halal food and...they wouldn't have alcohol, that was a given, it was just how halal the pool would be."[HH4]

The expectation of women-only facilities was also highlighted by one halal holiday expert who explained that this was an aspect of the holidays that most appealed to the women.

"The females probably have more to gain when it comes to travelling on a Halal holiday." [Expert2]

One interviewee shared her experience of going on a halal holiday and her sense of freedom at being able to visit the Hammam and the pool. This had obviously been a highlight of the halal holiday experience. 
"I love the beach, the pool and swimming and my daughter is the same. To have that opportunity now and feel comfortable is great. Before I would have felt so uncomfortable I just never would have done it... It was the little things for Mum as well, like the sauna, the Turkish Hamman, she loved it. She was like 'Oh my God I can't believe how much I have missed out....The women's pool, there were absolutely no men...you could sunbathe and that was a first for me. I am 32 and this is the first time I have been able to swim by the pool without a headscarfon and in the sun. I have never had a tan before!....I'd like to come on a holiday like this with my female friends. I noticed a lot of single or divorced ladies and I think this could be a good market - how else could we get away on our own?" [HH4]

It was not just the women however that discussed the expectation of women-only facilities. Male interviewees also discussed the importance of such women-only facilities and were acutely aware of the importance of such facilities for Muslim women.

"Women can find it quite intimidating if there are a lot of guys on the beach. A segregated swimming pool or beach facility was... a factor, not so much for me but for my wife."[HH1]

Dress codes

Throughout the discussions it was apparent that interviewees had different expectations about how other tourists on halal holidays should be dressed. While some women mentioned that should a women-only beach be provided at the resort they would want to wear the skimpiest bikini they could find, others expressed concern about how other women would dress. 
One interviewee discussed how they had found the level of undress by other Muslim women around the women-only pool distasteful and had not expected to see women in bikinis and swimming costumes.

"[It] was a proper shock because it's an Islamic resort. Of everything in the hotel that was the thing I felt most uncomfortable with, especially with an impressionable daughter there.[What] the women were wearing was too revealing. There's a difference of opinion of awrah [the parts of the body that should be covered in front of other women], at least your bottom if not anything else should be covered. So even if it was a pair of mini shorts [that would be ok], whereas with a bikini you can't even guarantee that because sometimes you are not completely covered. I went every day and I stayed but if I was to be honest I shouldn't have been looking at that. But you can't avoid it when it is in front of you in the pool, so for me I would probably say it's un-Islamic... If I was to go again I would definitely ring the hotels beforehand and ask if they have a dress code [for the pool]. As long as they say they do have a minimum dress code, as long as it's not a burqini because then there would be no point, I would feel a lot more comfortable." [HH4]

There were stark differences between the women regarding beach wear. While some were delighted by the thought of being able to relax on a beach and swim in a swimming costume, others would prefer more modest attire.

These differences were highlighted by the attitudes of PHH1 and PHH3, sisters of Lebanese birth who have lived in Qatar for most of their lives, towards using separate, women-only, facilities. PHH 3 said she would not go on holiday to a shared beach where "people [are] almost nude. People can be on a beach and be conservative...I don't wear swimming suit [sic]...I do ok with shorts and sweatpants." 
However, when asked what she would do on a private women's beach she replied: "I would wear the skimpiest bikini I could find!"

Her sister, PHH1, would not use a women-only beach that also had males over the age of seven years unless she was in a full-body burqini - a loose-fitting Muslim swimsuit which covers the entire body and usually incorporates trousers and a close-fitting hood.

Protecting children from alcohol and bad behaviour

Many interviewees discussed the importance of an environment that was suitable for families and children. Many spoke about the need to protect their children from haram behaviour and this was seen to be very important to many of the Muslims.

In particular many Muslims were concerned about their children seeing other tourists drunk and the expectation was that a halal holiday would not carry this risk.

“We feel it's safer a more family environment. We are not drinking alcohol which means most of the people are conscious they don't lose their mind, they don't do any bad things especially in front of our kids. So we are just protecting them [from] all these evil things." [HH2]

“When I choose a hotel, I want where there won't be a disco. Sometimes... with a disco you see them coming...if they get drunk and are in the lobby, I don't want my children to see drunk people.So when I look at the services of a five star hotel I like they don't have a nightclub." [PHH1] 
Some interviewees also expressed concern about their children seeing other tourists kissing in public and the expectation was that others taking a halal holiday would not act in this way.

"I expect not to see kissing in front of my boys, especially between [same gender]...it is very strange for us. The most important thing is the relation between men and woman not kissing in front of kids..... d don't want my boys to find [women in bikinis] a normal thing. I want them to know it is not allowed for us. We went to many swimming pools [in the UK] with my boys, we were telling them women can't go out like that in front of men but they were asking why. I said they are not Muslims and that is allowed in their religion. They are confused between what we are telling them and what they saw. This holiday would be different behaviour...." [PHH2]

"I wanted a family environment. There wasn't going to be alcohol, there wasn't going to be people acting in an awkward fashion. It [the Halal holiday] was a family-environment that we wanted and finding other like-minded families who [shared] our ethos.... as long as we were somewhere kids can be kids and you are in a safe family environment.... I was always scared of when considering taking the kids was loutish behaviour and alcohol-fuelled incidents. That was my biggest worry. I'm just worried about other people's behaviour which, obviously, you can't control."...." [HH3]

Muslim-friendly entertainment

There was the expectation that the entertainment on a halal holiday should be Muslim- friendly. One interviewee discussed the activities provided for children on the halal holiday they had been on. 
"Even kids' activities were peaceful. We know their minds are not spoiled...there were some questionnaires to know about the Prophet...it's so nice to have games about the Prophet... it's important to me that my daughter sees that, yes, we are Muslim and we are practicing and...we are quite modest how we dress, but that doesn't mean we can't have fun. It's just doing it in a way when you are not going against your religion... I want to have fun and it matters to me but I don't want to go against what I believe in." [HH2]

Another interviewee had experienced traditional Turkish dancing in their hotel with men and women dancing together. They described how upset their father had been with this as they saw it to be haram and had removed themselves from the entertainment and had complained to the Manager.

There was agreement that the entertainment should be suitable for families and children and in an atmosphere that did not compromise their Islamic values.

“...avoids confusion for children” [PHH2]

\section{'Living Islam'}

For some, the expectation of a halal holiday was that it gave them and their families the opportunity to 'live' Islam. For those who had been on a halal holiday the opportunity to stay in an Islamic nation was important. 
"I really liked the way people treated each other. Islamically that's how it should be. That's where my daughter's side comes into it: she is living Islam. She is hearing the azan [call to prayer] and seeing us praying and seeing us having fun but it is all Halal, so she is living it rather than us just preaching it when she is in England. She is seeing it happen." [HH4]

The expectation was that the destination would be an Islamic one and provide an opportunity for tourists to share in everyday life in that country.

\section{Discussion}

The study explores Muslim consumers' expectations of halal holidays. As well as identifying what Muslim consumers expect from a halal holiday, the study reveals expectations of what they did not wish to experience. These collectively provide a rich insight into expectations of halal holidays and extend our knowledge and understanding of halal tourism.

The study makes three main contributions to the literature. First, the study identifies those expectations which are likely to influence satisfaction, such as halal food and women-only beaches and pools. Second, the study identifies those expectations which are likely to cause dissatisfaction for halal holidaymakers. Alcohol, dancing and dress codes were some of the issues highlighted in the study. Third, the study reveals the difference in expectations which exist between halal holidaymakers and suggests that the interpretation and practice of Islam is highly varied. These findings have important implications for halal holiday organisations and mainstream tour operators wishing to target this growing tourism sector. 
First, the study identifies the facilities that Muslim consumers expect to find on a halal holiday. Many of these expectations were seen to be implicit, such as the availability of halal food and segregated facilities. Women-only facilities were seen to be a key expectation, with beaches, pools and spa and gym facilities also expected. Although the finding that halal holidays are expected to offer halal foods and women-only facilities may not be a novel contribution (Kärkkäinen, 2013), identifying the expectations that women have of using women-only facilities makes a significant contribution to our knowledge of halal tourists.

The expectation that a prayer room or mosque be provided in hotels and resorts was also an implicit one. This is important to note for holiday providers since such expectations need to be met if the service is to be judged as satisfactory.

Second, the study identifies a number of expectations which are likely to cause dissatisfaction for halal holidaymakers. The findings suggest that most of these relate to not being exposed to anything haram. The study highlights the expectation that a halal holiday is seen to be one that allows Muslim tourists to go on a holiday while remaining true to their religion. Not serving alcohol was an implicit expectation and this was seen to be a main attraction for going on a halal holiday. Although the literature has previously highlighted the need for halal holidays to be alcohol-free (Alserhan, 2011), it is valuable to gain insight into why Muslim tourists see this aspect as important and how it relates to their expectation that their faith should not be compromised (Din, 1989). This supports the notion that Muslim tourists seek holidays that will not cause them offence in any way (Hamza et al, 2012). Furthermore, it supports the framework offered by Wilson and Hollensen (2013) which identifies the importance of Islamic drivers and confirms the need for Muslims to uphold daily practice within their Islamic life. 
There was also the explicit expectation that Muslim tourists wished to protect their family from anything haram. The Findings suggest many factors relate to other tourists behaviour and dress and this is an important consideration for tourism companies. In particular there was concern that children were not exposed to inappropriate dress, alcohol or kissing in public. Dancing was also raised as problematic for some tourists. While the responsibility to observe halal is widely discussed in the literature (Al Jallad, 2008; Rehman et al, 2010), to date there has been little exploration of how this affects expectations of halal leisure holidays.

Third, the study identifies the differences that exist between Muslim tourists and how expectations of a halal holiday varies. This is an important consideration for halal tourism companies. While the literature warns against segmenting the Muslim market into one entity because of the difference in interpretation and practice of Islam (Sandikci, 2011; Suerdam, 2013), this study indicates how these differences manifest. The literature has previously identified that interpretation of Islam varies (Scott and Jafari, 2014; Stephenson, 2013) and this study provides evidence of how Muslim consumers interpret the provision of a halal holiday. Even within the small sample used in the study there were stark differences in expectations. This agrees with Wilson and Liu (2010) who argue that Muslim consumers should not be seen as a homogenous group. The expectations regarding what women should wear on the women-only beach or at the women-only pool was one example of this.

Understanding the nature of each Muslim tourist's expectations is therefore important and suggests more research is needed to understand the differences between Muslim consumers. 
The study confirms the challenge of identifying what makes a brand halal (Wilson and Liu, 2010, 2011). The findings highlight the need to take into account different interpretations of the halal phenomena and be sensitive to the consumers' needs and desires.

The study identifies the importance of understanding expectations in the halal holiday sector. Since expectations are seen to be the benchmark for confirmation/disconfirmation of service levels (Parasuraman et al, 1991; Zeithaml et al, 1993), understanding both explicit and implicit expectations (Gronroos, 2007; Ojasalo, 2001) is important. Although a number of rich insights were identified, the study highlights the need for greater examination of the nature of expectations in this domain.

\section{Managerial Implications, Limitations and Future Research}

Managing expectations is an important consideration for any service provider and those within the halal holiday sector need to ensure that expectations are carefully managed. Since interpretation of what constitutes a 'halal holiday' appears to vary between consumers there are inherent challenges in meeting expectations.

Halal holiday providers could consider for example developing an index or standard of 'halalness'. This could be a cross industry initiative to better inform consumers about the nature of the holiday services and facilities. Although this may be problematic due to the complex and varying interpretation of the religion, it could be that each resort supplies highly detailed information about their offering, such as the dress code for the women-only areas and entertainment, to inform consumers before booking.

The study also has a number of implications for the marketing of halal holidays. Although the focus of the study was on consumer expectations, the study provides a rich insight into the 
motivations for taking a halal holiday. The opportunity such a holiday afforded to consumers to 'Live' Islam, for example, is one aspect that could be developed by providers in their future marketing communications.

Although this was a small scale study that does not permit generalisations to be made, it does highlight the need for further research in this domain. Future research could explore the motivations of Muslim tourists in more depth. Furthermore, there is a need for a greater understanding of the differences between Muslim tourists and a larger scale study is warranted. 
Reference

s

Al Jallad, N., (2008) The concepts of al-halal and al-haram in the Arab-Muslim culture: a translational and lexicographical study. Language Design 10, 77-86. Retrieved from: http://elies.rediris.es/Language Design/LD10/LD 1002 Nader Pazeado.pdfhttp://elie s.redir is.es/Language Design/LD10/LD 1002 Nader Pazeado.pdf

Ali, D.A., Johari, F. \& Alias, M.H. (2014) Tracing the J-Curve Effect in Halal and non-Halal Beverages Industry in Malaysia. Asian Social Science 10(13), 222 - 230.

http://dx.doi.org/10.5539/ass.v10n13p222http://dx.doi.org/10.5539/ass.v10n13p22 $\underline{2}$

Alserhan, B. (2011). The Principles of Islamic Marketing. Farnham: Gower.

Battour, M., Ismail, M., \& Battor, M. (2011). The impact of destination attributes on Muslim tourist's choice. International Journal of Tourism Research, 13(6), 527-540. doi:10.1002/jtr.824

Brewerton, P., \& Millward, L. (2001). Organizational research methods [electronic resource] : a guide for students and researchers .London : SAGE

Coye, R. W. (2004). Managing customer expectations in the service encounter. International Journal of Service Industry Management, 15(1), 54-71.

Creswell, J. W. (2014). Research design : qualitative, quantitative, and mixed method approaches. $\left(4^{\text {th }}\right.$. ed). Los Angeles : Sage.

Denscombe, M. (2010). Ground Rules for Social Research: Guidelines for Good Practice $\left(2^{\text {nd }}\right.$ Ed.) Maidenhead: Open University Press.

Din, K. H. (1989). Islam and tourism. Patterns, issues, and options. Annals of Tourism Research, 16, 542-563. doi:10.1016/0160-7383(89)90008-X

Dinar Standard and Crescentrating LLC (2012). Global Muslim Lifestyle Tourism Market 2012: Landscape \& Consumer Needs Study For Airlines, Destinations \& Hotels/Resorts Executive Summary (2012, July). Retrieved from: 
http://www.crescentrating.com/halal- friendly-travel-ebooks-presentationsdownloads/view document/9-global-muslim-lifestyle- tourism-market-2012report.html 
Dudley, D. (2013). Halal market sees rapid growth. MEED: Middle East Economic Digest, 57(45), 24-25.

Galletta, A. (2012). Mastering the Semi-structured Interview and Beyond : From Research Design to Analysis and Publication. New York: New York University Press.

Grönroos, C. (2007). Service management and marketing : customer management in service competition. $\left(3^{\text {rd }}\right.$. ed). Chichester : John Wiley.

Hamza, I. M., Chouhoud, R., \& Tantawi, P. (2012). Islamic Tourism: Exploring Perceptions \& Possibilities in Egypt. African Journal Of Business \& Economic Research, 7(1), 85-98.

Karkkainen L.\& Islam, A., (2013) Islamic tourism as a prosperous phenomenon in Lapland. (Unpublished degree thesis). Rovaniemi University Of Applied Sciences, Rovaniemi, Finland. Retrieved from:

https://www.theseus.fi/bitstream/handle/10024/65659/Thesis Aminul Laura.pdf?se quence $=1$

https://www.theseus.fi/bitstream/handle/10024/65659/Thesis Aminul Laura.pdf?se quence $=1$

Miles, M. B., Huberman, A. M., \& Saldaña, J. (2014). Qualitative data analysis: a methods sourcebook. Los Angeles : SAGE

Mitchell, V. W., \& Greatorex, M. M. (1993). Risk Perception and Reduction in the Purchase of Consumer Services. Service Industries Journal, 13(4), 179-200.

Mukhtar, A.\& Mohsin Butt, M. (2012) Intention to choose Halal products: the role of religiosity, Journal of Islamic Marketing, 3(2), 108-120. doi:

$\underline{10.1108 / 17590831211232519}$

Newman, I., \& Benz, C. R. (1998). Qualitative-quantitative Research Methodology: Exploring the Interactive Continuum. Carbondale: Southern Illinois University Press.

Nursanty, E., (2013) Halal Tourism, The New Product In Islamic Leisure Tourism And Architecture. Retrieved from:

http://www.academia.edu/2218300/Halal Tourism The New Product In Islamic Lei sure Tourism And Architecture 
Ojasalo, J. (2001). Managing customer expectations in professional services.

Managing Service Quality, 11(3), 200-212. doi:10.1108/09604520110391379 
Oliver, P. (2006). Purposive Sampling. In (Ed.) V. Jupp \& Sage Publications. The SAGE Dictionary of Social Research Methods, (pp.244-245).London: SAGE Publications.

Oliver, R. (1977) Effect of expectation and disconfirmation on post-exposure product evaluations: An alternative interpretation. Journal of Applied Psychology, 62(4), 480-486. doi: 10.1037/0021-

9010.62.4.480http://psycnet.apa.org/doi/10.1037/0021-9010.62.4.480

Parasuraman, A., Berry, L. L. and Zeithaml, V. A. (1991). Understanding customer expectations of service. Sloan Management Review 32(3), 39-48.

Pavlova, I. (2011). Bosnia sees high promise in halal tourism. SEE Top 100. 120-121. Retrieved from: http://connection.ebscohost.com/c/articles/78124580/bosniasees-high- promise-halal-

tourismhttp://connection.ebscohost.com/c/articles/78124580/bosnia-sees- highpromise-halal-tourism

Pearce, P. L. (2005). Tourist behaviour [electronic resource]: themes and conceptual schemes. Retrieved from:

http://eds.b.ebscohost.com/eds/detail/detail?vid=6\&sid=92e0185d- 5f63-4a48-bb13d199a590c204\%40sessionmgr114\&hid=102\&bdata=JnNpdGU9ZWRzLWxpdmU\%3d\# $\mathrm{db}=\mathrm{c}$ at01619a\&AN $=$ up. 751500

Prayag, G., \& Hosany, S. (2014). When Middle East meets West: Understanding the motives and perceptions of young tourists from United Arab Emirates. Tourism Management, 40, 35- 45. doi:10.1016/j.tourman.2013.05.003

Reeve, C., (2012, November 12). Halal tourism's moment in the sun. CNN. Retrieved from: http://travel.cnn.com/halal-tourism-329146

Rehman, A., Shabbir, M. \& Gill, S. (2010). The relationship between religiosity and new product adoption. Journal Of Islamic Marketing 1(1), 63-69.

Salleh, N. Z. M., Hamid, A. B. A., Hashim, N. H., \& Omain, S. Z. (2014).The Practice of Shariah-Compliant Hotel in Malaysia. International Journal of Trade, Economics and Finance, 5(1), 26-30. doi: 10.7763/IJTEF.2014.V5.335 
Sanad, H., Kassem, A.M., \& Scott, N. (2010). Chapter 2 Tourism and Islamic law, in Noel Scott, Jafar Jafari (ed.) Tourism in the Muslim World (Bridging Tourism Theory and Practice, 
Volume 2), (pp.17-30). Emerald Group Publishing Limited. doi: $\underline{10.1108 / S 2042-}$

1443(2010)0000002005http://dx.doi.org/10.1108/S2042$\underline{1443(2010) 0000002005}$

Sandikci, Ö. (2011). Researching Islamic marketing: past and future perspectives. Journal of Islamic Marketing, 2(3), 246-258.

Shakona, M., Backman, K., Backman, S., Norman, W., Luo, Y., \& Duffy, L. (2015). Understanding the traveling behavior of Muslims in the United States. International Journal of Culture, Tourism and Hospitality Research, 9(1), 22-35.

Suleaman, N. (2010, August 28) The birth of halal holidays. The Guardian. Retrieved from: http://www.theguardian.com/travel/2010/aug/28/halal-holidays-turkeymuslim- womenhttp://www.theguardian.com/travel/2010/aug/28/halal-holidaysturkey-muslim-women

Stephenson, M. L. (2013). Deciphering 'Islamic hospitality': Developments, challenges and opportunities. Tourism Management, 40, 155-164.

doi:10.1016/j.tourman.2013.05.002

Strauss, A. L., \& Corbin, J. M. (1998). Basics of qualitative research : techniques and procedures for developing grounded theory. $\left(2^{\text {nd }}\right.$. ed) London: Sage.

Suerdem, A. A. (2013). Yes my name is Ahmet, but please don't target me. Islamic marketing: Marketing IslamTM?. Marketing Theory, 13(4), 485-495.

Talib, M., Hamid, A., Zulfakar, M. \& Jeeva, S. (2014) Halal Logistics PEST Analysis: The Malaysia Perspectives. Asian Social Science. 10(14).

http://dx.doi.org/10.5539/ass.v10n14p119http://dx.doi.org/10.5539/ass.v10n14p1 19 http://dx.doi.org/10.5539/ass.v10n14p119

Temporal, P. (2011). Islamic branding and marketing : creating a global Islamic business . Chichester: Wiley

Venkatesh, A. (1995). Ethnoconsumerism: A new paradigm to study cultural and cross- cultural consumer behavior. In J. Costa, G. J. Bamossy (Eds.) , Marketing in a multicultural world: Ethnicity, nationalism, and cultural identity (pp. 26-67). Thousand 
Oaks: Sage

Wilson, J. A., Belk, R. W., Bamossy, G. J., Sandikci, Ö., Kartajaya, H., Sobh, R., Liu, J \& Scott, L. (2013). Crescent marketing, Muslim geographies and brand Islam: reflections from the JIMA Senior Advisory Board. Journal of Islamic Marketing, 4(1), 22-50. 
Wilson, J. A., \& Hollensen, S. (2013). Assessing the implications on performance when aligning customer lifetime value calculations with religious faith groups and after lifetime values-a Socratic elenchus approach. International Journal of Business Performance Management, 14(1), 67-94.

Wilson, J. A. (2014). The halal phenomenon: An extension or a new paradigm?. Social Business, 4(3), 255-271.

Wilson, J. A., \& Liu, J. (2011). The challenges of Islamic branding: navigating emotions and

halal. Journal of Islamic Marketing, 2(1), 28-42.

Wilson, J. A., \& Liu, J. (2010). Shaping the Halal into a brand?. Journal of Islamic Marketing, 1(2), 107-123.

Yüksel, A., \& Yüksel, F. (2001). The Expectancy-Disconfirmation Paradigm: A Critique. Journal Of Hospitality \& Tourism Research, 25(2), 107.

doi:10.1177/109634800102500201

Zamani-Farahani, H., \& Henderson, J. C. (2010). Islamic tourism and managing tourism development in Islamic societies: the cases of Iran and Saudi Arabia. International Journal of Tourism Research, 12(1), 79-89.

Zeithaml, V.A., Berry, L. L. and Parasuraman, A. (1993). The nature and determinants of customer expectations of service. Journal of the Academy of Marketing Science 21(1), 112. 
Table 1: Sample profile. Code: Expert $=$ Travel providers and marketers. $\mathrm{HH}=$ Halal Holidaymaker PHH = Potential Halal Holidaymaker (Muslims who would like to go on a Halal holiday)

\begin{tabular}{|l|l|l|l|l|l|}
\hline & Gende & Age & Nationality & $\begin{array}{c}\text { No. of } \\
\text { childre } \\
\text { n/ }\end{array}$ & Occupation \\
\hline Expert & M & & Turkish & nrovider \\
\hline Expert & M & & British & n/ & Travel provider \\
\hline Expert & F & & British & n/ & Marketer \\
\hline \hline HH 1 & M & 34 & Azerbaijani & 3 & Businessman \\
\hline HH 2 & F & 35 & Azerbaijani & 3 & Maternity leave \\
\hline HH 3 & F & 36 & British- & 3 & GP \\
\hline HH 4 & F & 32 & British-Libyan & 1 & Dentist \\
\hline PHH 1 & F & 41 & Lebanese & 2 & Museum \\
\hline PHH 2 & M & 36 & Saudi Arabia & 3 & Student \\
\hline PHH 3 & F & 39 & Lebanese & 0 & Banker \\
\hline PHH 4 & F & 35 & British & 2 & Teacher \\
\hline PHH 5 & M & 36 & Bangladesh & 1 & Artist/poet \\
\hline \hline
\end{tabular}

